\title{
Microcosm studies of the role of land plants in elevating soil carbon dioxide and chemical weathering
}

\author{
C. Baars,${ }^{1,2}$ T. Hefin Jones, ${ }^{3}$ and Dianne Edwards ${ }^{1}$ \\ Received 2 April 2008; revised 13 May 2008; accepted 28 May 2008; published 21 August 2008.
}

[1] A decrease in atmospheric carbon dioxide $\left(\mathrm{CO}_{2}\right)$ concentration during the midPalaeozoic is postulated to have been partially the consequence of the evolution of rooted land plants. Root development increased the amount of carbonic acid generated by root respiration within soils. This led to increased chemical weathering of silicates and subsequent formation of carbonates, resulting in lower atmospheric $\mathrm{CO}_{2}$ concentrations. To test this assumption, analog (morphologically equivalent) plant species, ranging from those possessing no roots to those with complex rhizomatous rooting systems, were grown in trays within microcosms at ambient $(360 \mathrm{ppm} / 0.37 \mathrm{mbar})$ and highly elevated (3500 ppm/3.55 mbar) atmospheric $\mathrm{CO}_{2}$ concentrations in a controlled environment facility. Substrate $\mathrm{CO}_{2}$ concentrations increased significantly under elevated atmospheric $\mathrm{CO}_{2}$, and Equisetum hyemale (L.). The latter is postulated to result from the effects of deeply rooted plants, elevated atmospheric $\mathrm{CO}_{2}$ concentrations, or both. Plants with simple or no rooting systems or the addition of dead organic matter as a substrate for microorganisms did not enhance substrate $\mathrm{CO}_{2}$ concentrations.

Citation: Baars, C., T. Hefin Jones, and D. Edwards (2008), Microcosm studies of the role of land plants in elevating soil carbon dioxide and chemical weathering, Global Biogeochem. Cycles, 22, GB3019, doi:10.1029/2008GB003228.

\section{Introduction}

[2] Colonization of the terrestrial environment is generally accepted to have occurred in several phases. The first of these phases comprised microbial mats of bacteria, cyanobacteria, algae and fungi [Wright, 1985; Edwards and Selden, 1993; Nisbet and Fowler; 1999]. This was followed in the mid-Ordovician to late Silurian by diversification of small plants with embryophytic affinities, partially exhibiting bryophytic characteristics (the Eoembryophytic and Eotracheophytic of Gray [1993]) of possibly axial organization, which grew among the communities of thalloid organisms and cyanobacteria comparable to modern biological soil crusts [Tomescu et al., 2006]. Increased height and complexity of sporophytic branching patterns, facilitated by the evolution of xylem and homoiohydry, led to a new vegetation type with increased subaerial biomass. These species first became abundant in the Ludlow (late Silurian), with global proliferation in the Lower Devonian [Edwards, 2003], and many are thought to have exhibited clonal growth with limited underground rhizomatous systems, but no roots [Kerp et al., 2001]. Present in this vegetation were the earliest lycophytes with true roots [Gensel and Berry, 2001], heralding a new wave of vegetation in the

\footnotetext{
${ }^{1}$ School of Earth, Ocean and Planetary Sciences, Cardiff University, Cardiff, UK.

${ }^{2}$ Now at Department of Geology, National Museum Wales, Cardiff, UK.

${ }^{3}$ School of Biosciences, Cardiff University, Cardiff, UK.

Copyright 2008 by the American Geophysical Union. 0886-6236/08/2008GB003228
}

Devonian of plants of diverse lineages, but with even more complex rooting systems in volume and depth [Raven and Edwards, 2001; Algeo and Scheckler, 1998]. It was the advent of such systems, particularly in well-drained upland soils [Berner, 1998], that is thought to have accelerated the decrease in atmospheric $\mathrm{CO}_{2}$ by increasing chemical weathering [Driese et al., 2000; Algeo and Scheckler, 1998; Retallack, 1997; Holland, 1978].

[3] Land plants affect chemical weathering in several different ways. They actively secrete organic acids into the soil environment to extract essential nutrients from minerals [Jones et al., 1996], and provide dead organic matter for decomposition by microorganisms which also release organic acids into the soil [Killham, 1994]. Additionally, the respiration of plant rooting structures and soil organisms increases soil $\mathrm{CO}_{2}$ concentration. $\mathrm{CO}_{2}$ reacts with soil water to form carbonic acid. Soil respiration therefore increases the carbonic acid levels within soils. Carbonic acid is the most abundant acid on Earth [Brady and Zachara, 1996]; rainwater is naturally acidic largely because of its effects.

[4] Only about $15 \%$ of present-day total soil $\mathrm{CO}_{2}$ concentration is derived directly by diffusion from the atmosphere [Ghosh et al., 1995], the remainder originates indirectly from soil respiration: belowground plant [Lambers et al., 1996; Baxter et al., 1997] and microbial respiration due to increased supply of plant-derived organic matter through rhizodeposition or dead organic matter [Nguyen, 2003; see also Cardon, 1996]. Consequently, current soil $\mathrm{CO}_{2}$ concentrations can be up to 100 -fold higher than atmospheric $\mathrm{CO}_{2}$ levels [Russell, 1973; Keller and Wood, 1993; Lambers et al., 1996]. Elevated atmospheric $\mathrm{CO}_{2}$ 
frequently results in further enhancement of soil respiration, plant and microbially derived [e.g., Gorissen, 1996; Andrews and Schlesinger, 2001; see also Oh and Richter, 2004].

[5] Carbonic acid dissolves silicate minerals at atmospheric temperatures [Busenberg and Clemency, 1976; Brantley, 2003]. The weathering products, including, significantly, the base cations calcium and magnesium, are transported to the ocean where they are precipitated biogenically or abiogenically as carbonates [Holland, 1978]. This process removes bicarbonate from the oceans, sequestering it over geological time in the lithosphere [Urey, 1952; Berner, 1992]. These processes can be summarized by the reaction:

$$
\mathrm{CO}_{2}+\mathrm{Ca} / \mathrm{MgSiO}_{3} \leftrightarrow \mathrm{Ca} / \mathrm{MgCO}_{3}+\mathrm{SiO}_{2}
$$

[6] The chemical equilibrium between atmosphere and ocean is maintained by the dissolving of further atmospheric $\mathrm{CO}_{2}$ in the ocean. An increase in chemical weathering therefore decreases atmospheric $\mathrm{CO}_{2}$ levels as more $\mathrm{CO}_{2}$ is dissolved [Dessert et al., 2003]. This implies the presence of a feedback mechanism: a higher atmospheric $\mathrm{CO}_{2}$ concentration increases chemical weathering which lowers atmospheric $\mathrm{CO}_{2}$ and this, in turn, decreases chemical weathering [Brady and Carroll, 1994]. Over geological time, the gains of $\mathrm{CO}_{2}$ (from, for example, volcanic releases of $\mathrm{CO}_{2}$ and carbonate weathering) have been fractionally smaller than losses to the lithosphere. Yet these losses have not been trivial and have led to the net removal of carbon from the atmosphere [Holland, 1978].

[7] While generally accepted that plants enhance chemical weathering, there is still discussion regarding the exact role different plant types played during the mid-Palaeozoic. Boucot and Gray [2001] have challenged Berner's [1998] view that chemical weathering increased only with the advent of rooted plants by suggesting the presence of nonrooted plants may have also contributed substantially. Others have suggested that even simple systems such as lichens, microbial mats and bryophytes [e.g., Jackson and Keller, 1970] can affect the dissolution of silicate minerals. Berner [1990] recognized the lack of knowledge of the role of nonvascular land plants on weathering by including a wide range of error in his model.

[8] Information on the potential effects of plants on chemical weathering has generally been obtained from field studies [Bormann et al., 1998; Moulton et al., 2000; Bohlen et al., 2001; Aghamiri and Schwartzman, 2002], the results of which can frequently be difficult to interpret because of the complexity of the processes involved. Field studies also often suffer from insufficient replication and low precision in vegetation and soil analyses [Binkley et al., 2000]. Experimental work to explore the effects of different vegetation types, which has the potential to address these factors, has not yet been undertaken.

[9] To explore the potential of plants to introduce respiration-derived $\mathrm{CO}_{2}$ into soil, different plant types, representing different taxa that are analogs of different stages in rooting system and biomass evolution were grown in a purpose-built controlled environment facility under two atmospheric $\mathrm{CO}_{2}$ regimes. Elevated $\mathrm{CO}_{2}$ treatment was at levels that were likely prevalent during early stages of plant evolution, and the control was at current ambient atmospheric $\mathrm{CO}_{2}$ levels. Plants were chosen following McElwain and Chaloner's [1995] "nearest living equivalent (NLE) species" concept. NLE species are defined as extant species that show ecological and/or structural similarity to the fossil plants with which they are being compared. Study organisms were chosen as analogs of plants with no underground organs (algae: > 90\% Schizochlamys gelatinosa A. Braun; Chlorophyta), plants with rhizoids (various bryophytes: mainly Conocephalum conicum (L.) Dum. and Leptobryum pyriforme (Hedw.)), and tracheophytes either nonrooted with rhizomatous rooting systems (Psilotum nudum (L.) Griseb.) or with very extensive rooting structures (Equisetum hyemale (L.)). The controlled environment microcosm approach allows accurate control and determination of factors such as temperature, humidity, substrate and composition of plant cover. Factors which can make interpretation of results difficult were excluded, for example, temperature/humidity fluctuations, nonuniform soil conditions, and the activities of soil fauna and burrowing animals. As with comparable microcosm experiments [e.g., Lawton, 1996], this empirical approach also allows studies to be kept as simple as possible, yet sufficiently realistic to be useful. It is not an attempt to imitate nature, but to reduce natural complexity to focus on the key questions.

[10] The study was divided into two phases. Phase I was aimed at determining whether plant community species composition, in particular, rooting structures, affected the concentration of dissolved $\mathrm{CO}_{2}$ recorded in the leachate collected from the microcosms. We hypothesized that substrate $\mathrm{CO}_{2}$ concentrations of the algae and control trays would reflect only direct atmospheric effects, with increasingly greater belowground systems (rhizoids, rhizome plus rhizoids, roots) introducing increasingly more $\mathrm{CO}_{2}$ into the substrate. Plants were grown at both ambient and highly elevated atmospheric $\mathrm{CO}_{2}$ (10 times ambient). This level was derived from estimates of Devonian (416-359 Ma) palaeoatmospheric $\mathrm{CO}_{2}$ concentrations [e.g., Mora et al., 1991; Berner and Kothavala, 2001]. In Phase II additional organic matter was added to the substrate, simulating natural turnover of soil organic matter (SOM) and bioturbation. Decomposing material should provide improved resources for microbial growth and consequently enhancement of microbial respiration.

\section{Material and Methods}

[11] A controlled environment facility (CEF) was constructed in a rooftop greenhouse at Cardiff University (Figure 1). The facility comprised 10 clear acrylic cabinets (400 $\mathrm{mm}$ width, $800 \mathrm{~mm}$ depth and $1000 \mathrm{~mm}$ height), where temperature, humidity, irrigation and atmospheric $\mathrm{CO}_{2}$ could be electronically controlled. No supplementary illumination was provided. The 10 cabinets were divided into two separate banks of five cabinets each: one bank with an atmosphere of elevated (3.55 mbar; treatment) and the other with ambient (0.37 mbar; control) atmospheric $\mathrm{CO}_{2}$.

[12] Three replicates of each of the four model analogs, along with one no-plant control (bare of any vegetation), 


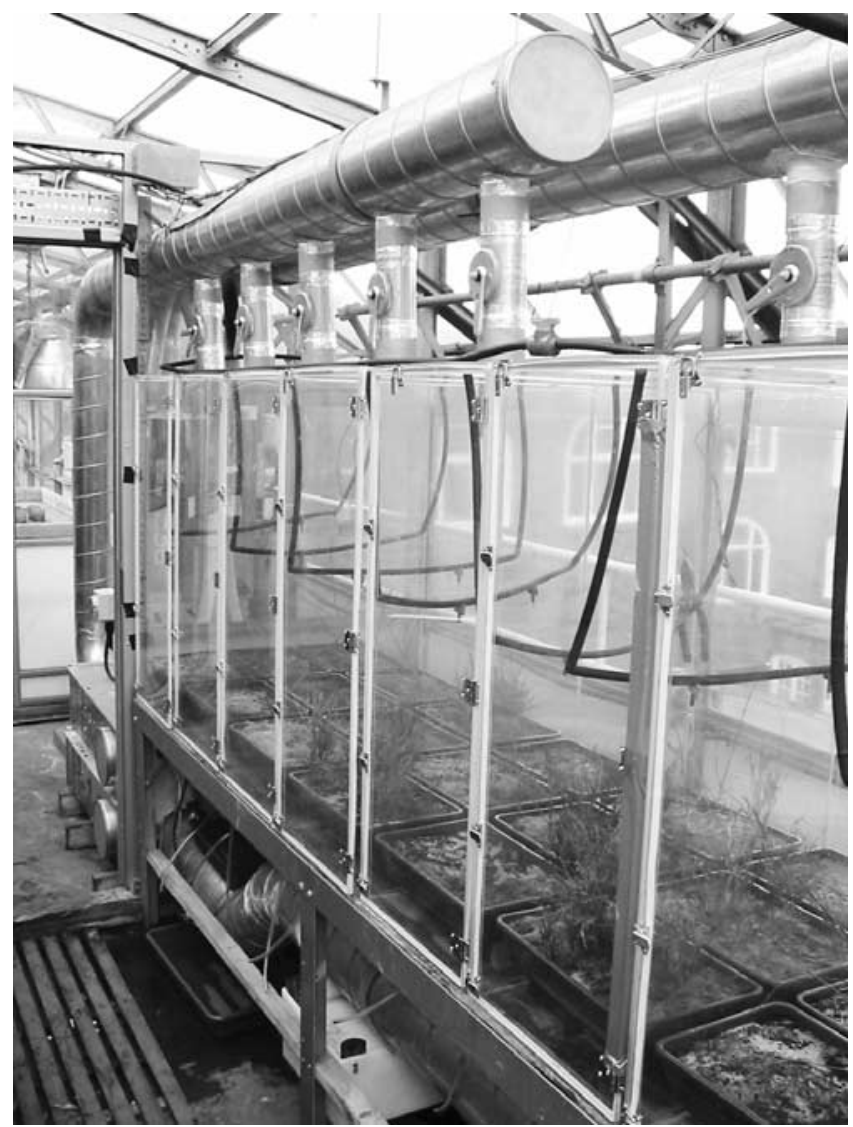

Figure 1. Seven of the ten controlled environment facility (CEF) cabinets inside the rooftop greenhouse; visible also the galvanized ducting for ventilation on top of and beneath the cabinets, the black irrigation tubes, and plant trays containing substrate and plants. Each cabinet is $40 \mathrm{~cm}$ wide.

were established in seed trays $(380 \times 240 \times 75 \mathrm{~mm})$. The model analogs of algae, bryophytes, Psilotum nudum (L.) Griseb. and Equisetum hyemale (L.) (collectively referred to as "plants" henceforth) were established on a substrate of silica sand and peat (sand: Nippon Electric Glass, Cardiff; peat: commercially available moss peat (due to concerns that plants would not grow on pure sand); both constituents dried at $65^{\circ} \mathrm{C}$ and weighed prior to mixing). The plants were acclimated to the CEF environmental conditions for 6 weeks prior to initiation of Phase I. This lasted 30 weeks (MarchSeptember 2002). Phase II lasted 43 weeks (October 2002 to July 2003) and was initiated by introducing additional organic matter (dead plant material, grown during Phase I, harvested, weighed, shredded) into the substrate. In an attempt to minimize the consequences of pseudoreplication, ambient and elevated atmospheric $\mathrm{CO}_{2}$ conditions were alternated between banks every two months, and the respective plant trays transferred to the same atmospheric conditions in the opposite bank. To minimize location effects within each treatment, trays were rotated within each bank in a random fashion on a weekly basis. The new positions of the trays were determined using a random number generating computer program.
[13] Substrate $\mathrm{CO}_{2}$ concentrations were measured indirectly: leachate, which preliminary measurements showed had the same dissolved total $\mathrm{CO}_{2}$ concentration as the substrate pore spaces, was collected from each microcosm in $40 \mathrm{ml}$ bottles. The full bottles were sealed until analysis, which was undertaken within a few hours of the samples being taken. Dissolved total $\mathrm{CO}_{2}$ concentrations were measured using a $\mathrm{CO}_{2}$ electrode (Diamond General 501 Mini) and millivolt meter.

[14] Leachate samples were also analyzed for organic acids: oxalic, citric, malic, malonic, lactic, propionic and $\alpha$-ketogluconic acids (Spectra Physics AS3500 HPLC, with a Supelco Supelcogel C-610H 59320-U 117-8E29 column packed with sulfonated polystyrene divinylbenzene, and Spectra Physics Spectra 100 variable wavelength analyzer at $210 \mathrm{~nm}$ ).

[15] Total plant air-dried biomass was measured at the end of the experiment. Belowground ("root") and above ground ("shoot") biomass were measured separately for E. hyemale and $P$. nudum plants; in bryophytes whole plant biomass was measured.

[16] Microbial activity was measured as dehydrogenase activity (DHA) using 2,3,5-triphenyltetrazolium chloride (TTC) as an alternative to oxygen as the electron acceptor during intracellular NAD(P) metabolism. TTC is reduced to triphenyl formazan (TPF), and microbial activity may be measured as TPF concentration (adapted from Öhlinger [1996]). Samples (5 g substrate) were collected as one per replicate plant and treatment (total: 30 ) at the end of Phase II.

[17] Differences between $\mathrm{CO}_{2}$ and plant treatments were tested using analysis of variance (two-way ANOVA; repeated measures ANOVA in the case of substrate $\mathrm{CO}_{2}$ concentration to account for the effects of time). Significance between treatments was determined using Duncan's post hoc test.

\section{Results}

[18] Substrate $\mathrm{CO}_{2}$ concentration generally increased ( $p<$ 0.001 ) under conditions of elevated atmospheric $\mathrm{CO}_{2}$ levels. The bryophytes and both tracheophytes increased substrate $\mathrm{CO}_{2}$ values by approximately 10 mbar in elevated atmospheric $\mathrm{CO}_{2}$ compared with the ambient baseline (Figure 2), while the substrate $\mathrm{CO}_{2}$ increases in algae $(3.7 \mathrm{mbar})$ and control $(5.2 \mathrm{mbar})$ were approximately equivalent to the atmospheric $\mathrm{CO}_{2}$ elevation (3.19 mbar). The interaction between atmospheric $\mathrm{CO}_{2}$ and plant treatment was not significant, with the substrate $\mathrm{CO}_{2}$ increase under elevated conditions being similar in all plant treatments.

[19] There were marked differences in substrate $\mathrm{CO}_{2}$ concentrations between different plant types $(p<0.001)$. $E$. hyemale yielded the highest (approximately $27 \%$ higher) under both ambient and elevated atmospheric $\mathrm{CO}_{2}$ (Figure 2). The differences between nonrooted plant communities were small, showing similar substrate $\mathrm{CO}_{2}$ values under both atmospheric $\mathrm{CO}_{2}$ treatments (Figure 3). During Phase I, substrate $\mathrm{CO}_{2}$ under $E$. hyemale was significantly higher than in all other plants (Duncan's post hoc test, Figure 2). There were no significant differences between the remaining plant type treatments. For Phase II, E. hyemale exhibited the highest substrate $\mathrm{CO}_{2}$ values, bryophytes and $P$. nudum 

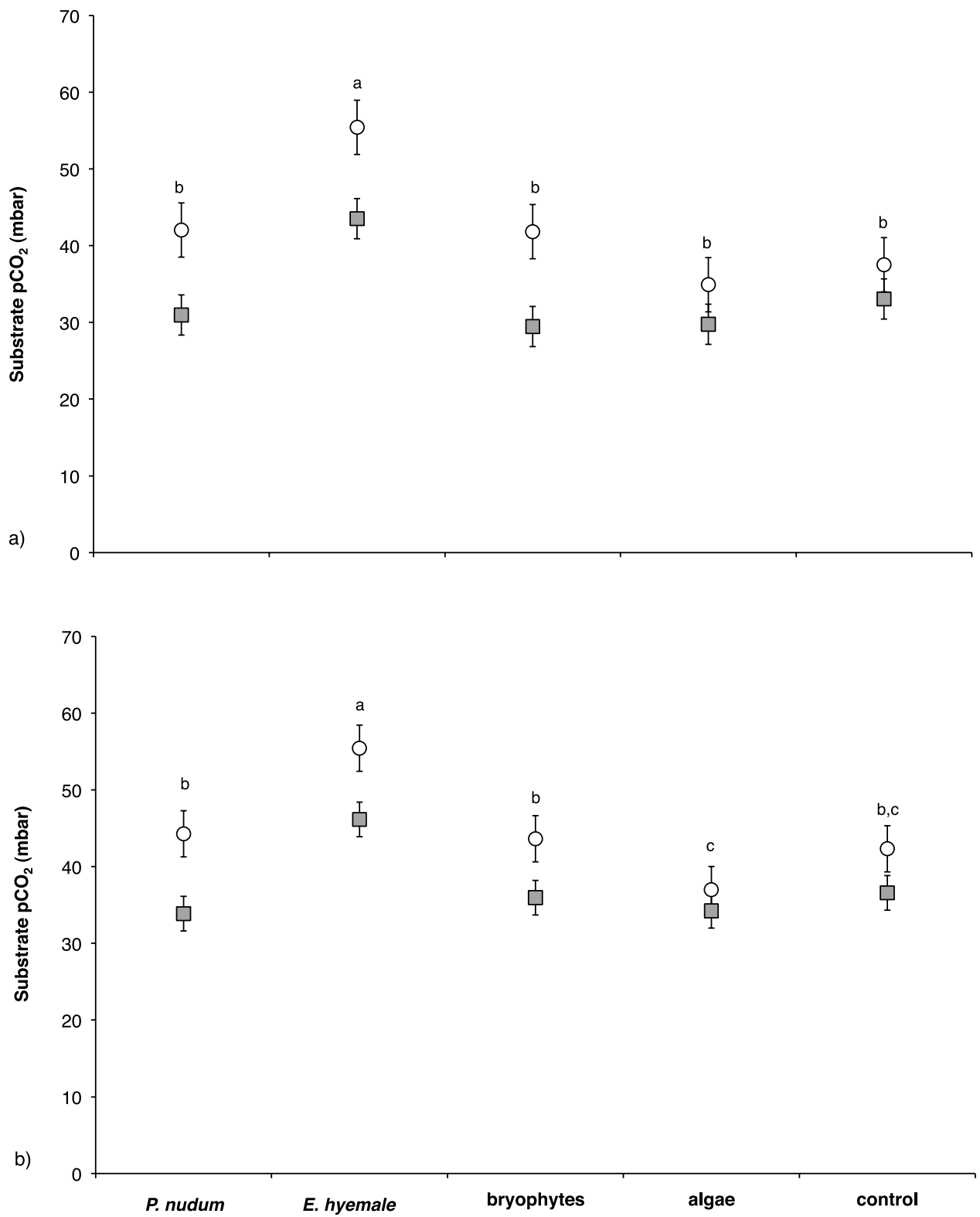

Figure 2. Mean substrate $\mathrm{CO}_{2}$ values $\left(p \mathrm{CO}_{2}\right)$ under ambient (shaded) and elevated (unshaded) atmospheric $\mathrm{CO}_{2}$ in the experimental plants; (a) Phase I. (b) Phase II. Values reported as mean values ( \pm standard error) of all available replicates at each of the seven (Phase I) and ten (Phase II) sampling dates. Letters indicate significance levels of Duncan's post hoc test; columns with the same letter code are not significantly different from $p=0.05$.

significantly lower, and algae and controls with the smallest values (Figure 2).

[20] There was no increase in substrate $\mathrm{CO}_{2}$ following the introduction of additional organic matter into the substrate at the beginning of Phase II (Figure 3). Substrate $\mathrm{CO}_{2}$ initially decreased on addition of organic matter in all microcosms before subsequent recovery to Phase I levels.

[21] Whole plant biomass (dry weight) differed significantly between plant treatments $(p=0.002$, Table 1$)$. The highest mean total biomass per tray was recorded in the bryophytes, and was more than twice that of $P$. nudum
(Figure 4); P. nudum had a higher total biomass than $E$. hyemale. Biomass increases under elevated atmospheric $\mathrm{CO}_{2}$ were not significant (Figure 4 and Table 1).

[22] Microbial activity was very low (Figure 5) in all plant and both $\mathrm{CO}_{2}$ treatments. There were significant differences ( $p=0.015$; Table 1) between plant treatments: mean DHA was greater for bryophytes and $P$. nudum than for the other plants and control. Differences between $\mathrm{CO}_{2}$ treatments were not significant ( $p=0.089$; Table 1$)$.

[23] Generally no organic acids were detected. The only acid recorded occasionally, and completely randomly dis- 

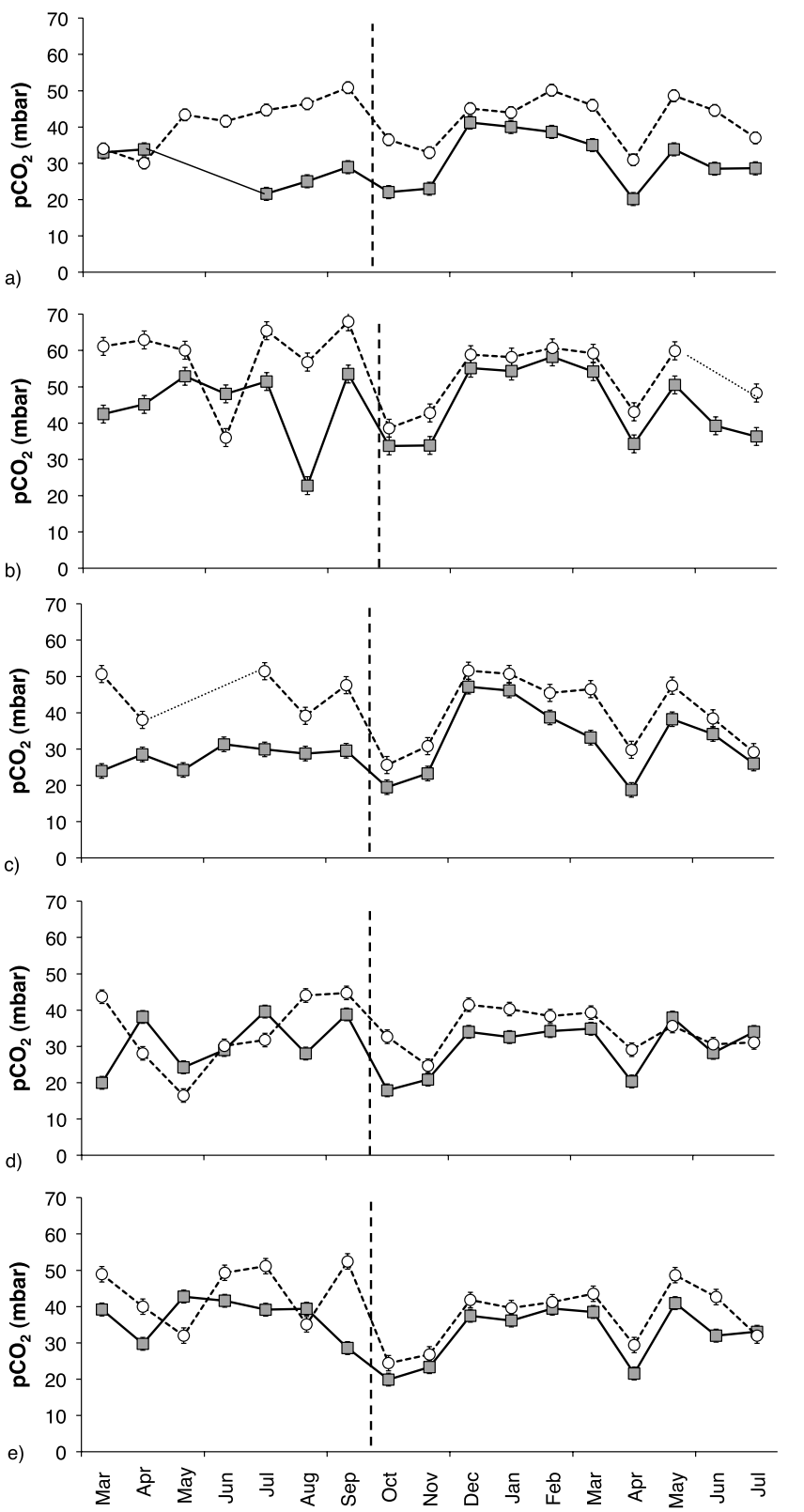

Figure 3. Mean ( \pm standard error) substrate $\mathrm{CO}_{2}$ values $\left(p \mathrm{CO}_{2}\right)$ for each month between March 2002 and July 2003; (a) P. nudum, (b) E. hyemale, (c) bryophytes, (d) algae, (e) control. (shaded) Values at ambient atmospheric $\mathrm{CO}_{2}$; (unshaded) values at elevated atmospheric $\mathrm{CO}_{2}$. Vertical broken line marks the start of Phase II.

tributed among plant and $\mathrm{CO}_{2}$ treatments, was oxalic acid at concentrations between 1-35 $\mu$ Mol.

\section{Discussion}

[24] Substrate $\mathrm{CO}_{2}$ ranged between 16-87 mbar and was up to 130 times higher than atmospheric $\mathrm{CO}_{2}$. These concentrations cannot be solely due to diffusive equilibration with atmospheric $\mathrm{CO}_{2}$ and support Ghosh et al.'s [1995] argument that atmospheric $\mathrm{CO}_{2}$ in soil air makes up only a fraction of total soil $\mathrm{CO}_{2}$ and root and microbial respiration must play an important role [Högberg et al., 2001]. Substrate $\mathrm{CO}_{2}$ also increased under elevated atmospheric $\mathrm{CO}_{2}$ concentrations. This difference may have been expected as a result of increased total respiration from greater biomass production at elevated atmospheric $\mathrm{CO}_{2}$ concentrations [Lambers et al., 1996; Saralabai et al., 1997; Stöcklin and Körner, 1999; Poole et al., 2000]. However, in the present study, other than for the bryophytes, which showed significantly greater biomass under elevated atmospheric $\mathrm{CO}_{2}$, there was no such significant increase in plant growth.

[25] There was a distinct difference in biomass between types of plant: the bryophytes were the plants with the largest overall biomass. The bryophyte rhizoids formed an extremely dense, if somewhat shallow, network and may have the potential to affect $\mathrm{CO}_{2}$ concentrations in the substrate to the same level as the compact rhizome of the nonrooted tracheophytes. Nevertheless, substrate $\mathrm{CO}_{2}$ in bryophytes was statistically no higher than in the other plant treatments and control. The $P$. nudum rhizome was compact, filling a comparatively small volume of substrate; the potential presence of mycorrhizal fungi [Moteetee et al., 1996], although not observed, did not appear to compensate for the lack of roots with respect to $\mathrm{CO}_{2}$ produced by respiration. Having no belowground organs, the algae had not been expected to contribute to an increase in substrate $\mathrm{CO}_{2}$ concentrations.

[26] The only plant where substrate $\mathrm{CO}_{2}$ was significantly higher than the control trays was E. hyemale (rooted tracheophyte). Since the substrate organic content was the same and microbial respiration very similar, in all plants and treatments, the higher substrate $\mathrm{CO}_{2}$ level in E. hyemale must have been the result of greater total plant belowground respiration. E. hyemale rhizomes and roots were much branched: when the plants were dug up, E. hyemale had formed a dense network of rhizomes and roots which had exploited the whole volume of substrate available. It is most likely that the reason for the failure of vegetation cover other than rooted tracheophytes to contribute substantially to the substrate $\mathrm{CO}_{2}$ pool was the low substrate penetration of these other plant species. Others also found that the respiration rate in bulk soil (i.e., soil not penetrated by rooting organs) is much lower than in comparable soil compartments with roots [Baath and Wallander, 2003]; this may be either by the lack of $\mathrm{CO}_{2}$ being introduced by plants directly into the substrate, or microbial respiration not being fuelled by rhizodeposition [Högberg et al., 2001; ScottDenton et al., 2006].

[27] In the present study introduction of additional organic matter did not result in a significant increase in substrate $\mathrm{CO}_{2}$ production. This, it is assumed, failed to stimulate microbial activity. Generally, microbial activity [Binet et al., 1998] and decomposition rates of organic matter by microorganisms [Heisler, 1994] are increased by mixing of mineral soil with organic particles, as this leads to good substrate/ organic matter contact, fragmentation of litter and inoculation of litter with microflora [Douce and Crossley, 1982]. This, in turn, usually results in the generation of additional $\mathrm{CO}_{2}$. 
Table 1. ANOVA of Biomass and Microbial Measurements ${ }^{\mathrm{a}}$

\begin{tabular}{llrrrr}
\hline \multicolumn{1}{c}{ Variable } & Factor & \multicolumn{1}{c}{$\mathrm{SS}$} & $\mathrm{df}$ & \multicolumn{1}{c}{$\mathrm{F}$} & \multicolumn{1}{c}{$p$} \\
\hline Total biomass & $\mathrm{CO}_{2}$ & 61.46 & 1,17 & 4.12 & 0.065 \\
Total biomass & plants & 3410.908 & 2,17 & 114.26 & $<0.001$ \\
Total biomass & interaction & 107.211 & 2,17 & 3.59 & 0.060 \\
Shoot biomass & $\mathrm{CO}_{2}$ & 1.713 & 1,11 & 0.58 & 0.467 \\
Shoot biomass & plants & 187.587 & 1,11 & 63.94 & $<0.001$ \\
Shoot biomass & interaction & 0.911 & 1,11 & 0.31 & 0.593 \\
"Root" biomass & $\mathrm{CO}_{2}$ & 0.195 & 1,11 & 0.05 & 0.835 \\
"Root" biomass & plants & 1.204 & 1,11 & 0.29 & 0.607 \\
"Root" biomass & interaction & 8.767 & 1,11 & 2.08 & 0.187 \\
DHA & $\mathrm{CO}_{2}$ & 0.013 & 1,29 & 3.19 & 0.089 \\
DHA & plants & 0.003 & 4,29 & 4.05 & 0.015 \\
DHA & Interaction & 0.005 & 4,29 & 1.74 & 0.181 \\
\hline
\end{tabular}

${ }^{a}$ Biomass measurements were only undertaken at the end of the experiment. $\mathrm{CO}_{2}$ : different atmospheric $\mathrm{CO}_{2}$ levels (ambient or elevated); plants: four experimental plants plus control. DHA: dehydrogenase activity.

[28] Organic acids were not detectable in the experimental substrate. Several authors have suggested that organic acid concentrations in bulk soil are generally extremely low, being found in substantial concentrations only in soil microenvironments, for example, in the vicinity of microbial colonies and in the rhizosphere [Bennett and Casey, 1994; Drever and Vance, 1994; Ryan et al., 2001] where they fulfill an important role in the plant's acquisition of mineral nutrients [Dakora and Phillips, 2002]. This lack of organic acids in the bulk soil may have implications for chemical weathering: Chiu et al. [2002] found that concentrations of exchangeable potassium and magnesium are greater in the rhizosphere than in bulk soils, and Basu [1981] even considers the presence of unaltered potassium feldspars in pre-Silurian soils as an indication of absence of plants. In this study, the weathering effects of organic acids were negligible in our experiments compared with the ubiquitous carbonic acid. This contradicts Berner et al. [2003] who attributed plant-enhanced weathering mainly to the action of organic acids and chelates.

[29] In general, we are in agreement with Berner et al. [2003] that it is unlikely that nontracheophytic autotrophs (such as bryophytes) and nonrooted tracheophytes (such as $P$. nudum), despite their potentially high primary productivity, can increase the soil $\mathrm{CO}_{2}$ content on the same scale as comparatively deeply and extensively rooted tracheophytes (such as E. hyemale). Bryophytic rhizoids and the rhizome of $P$. nudum had poor substrate penetration, and, in the absence of a mechanism to transfer into the substrate additional $\mathrm{CO}_{2}$ produced by respiration/decomposition, contributed relatively less to total soil respiration than the rhizome, roots and root hairs of E. hyemale. It is this transfer of $\mathrm{CO}_{2}$ from the atmosphere into the soil that promotes the formation of carbonic acid [see $\mathrm{Oh}$ and Richter, 2004]. This contrasts with Boucot and Gray's [2001] suggestion that terrestrial pretracheophytic productivity, particularly bacterial, being equal to or even higher than that of tracheophytes, would have contributed to higher substrate $\mathrm{CO}_{2}$ levels. Productivity is important only if some mechanism exists to translocate carbon from the surface into soils. Bioturbation may have some role to play here, although deeply rooted plants appear to provide the bulk of this transfer by direct respiration and provision of a substrate for microbial activity.

[30] The inferred role of deeply rooted plants in increasing substrate $\mathrm{CO}_{2}$ concentrations also confirms Berner's [1997] hypothesis of an acceleration of plant-enhanced chemical weathering following the evolution of deep rooting in the Devonian (416-359 Ma). Roots allowed a number of novel ways to increase the acidity of soils, the most important being $\mathrm{CO}_{2}$ translocation, rather than simple diffusion. A speculative exception may be extremely highly productive nontracheophyte communities, coupled with the

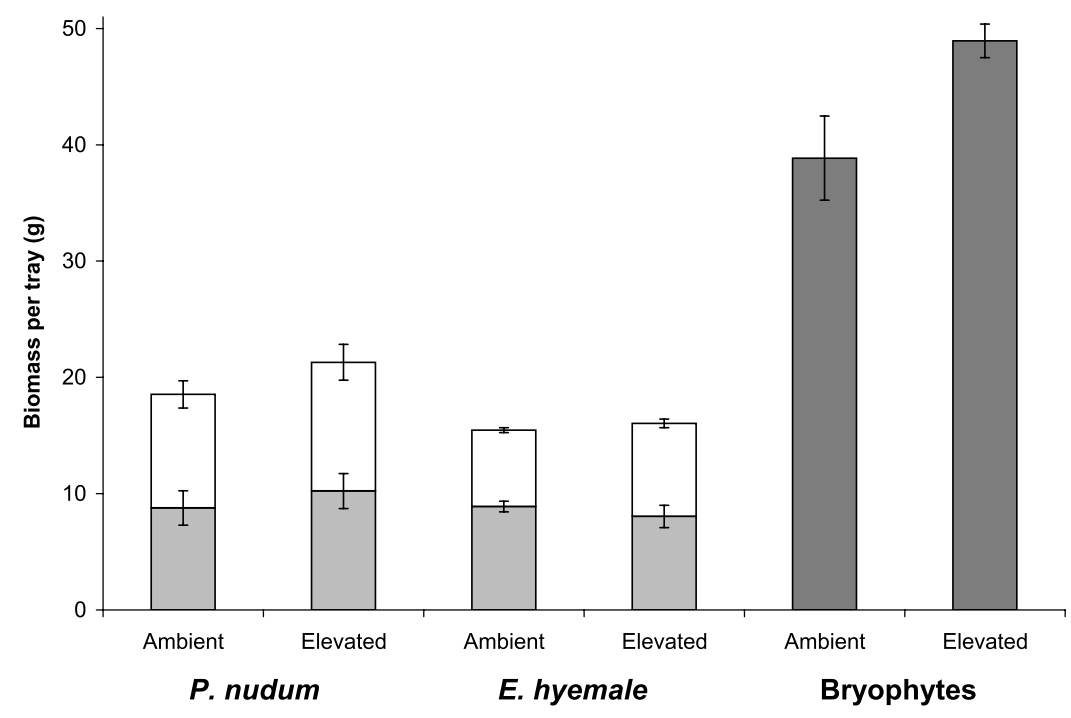

Figure 4. Mean ( \pm standard error) total biomass of plants under ambient and elevated atmospheric $\mathrm{CO}_{2}$ concentrations at the end of the experiment. P. nudum and E. hyemale "root" data (shaded) and "shoot" data (unshaded); for bryophytes, bars indicate total biomass. 


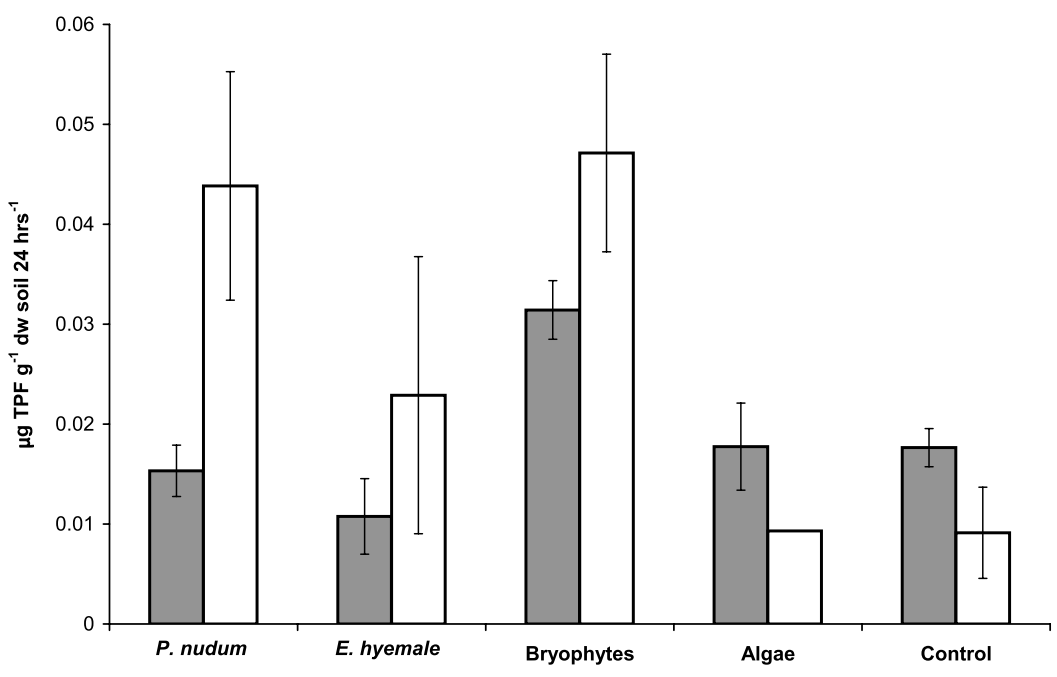

Figure 5. Mean microbial activity, measured as mean ( \pm standard error) $\mu \mathrm{g}$ triphenyl formazan (TPF) concentration per g dry weight soil over $24 \mathrm{~h}$. Ambient atmospheric $\mathrm{CO}_{2}$ (shaded); elevated atmospheric $\mathrm{CO}_{2}$ (unshaded) concentration. Significance levels: see Table 1.

vigorous activity of deeply burrowing detritivores, which transfer large amounts of organic matter from the soil surface to deeper horizons where microbial decay then increases the soil $\mathrm{CO}_{2}$ concentration. In this study, for example, bryophytes were very productive, and because they contain chemically less recalcitrant parenchymatous tissues compared with, for example, $P$. nudum, may decompose quickly, releasing $\mathrm{CO}_{2}$ into the substrate. The global contribution of plants with this level of plant-enhanced chemical weathering in the mid-Palaeozoic remains, however, a major uncertainty. A similar reservation relates to the distribution of rooted plants thus making quantitative estimates, such as Berner's plant weathering factor, difficult to achieve.

[31] Although not tested in this study it follows from observations on algae and bryophytes that biological soil crusts or lichens, although contributing to chemical weathering [e.g., Jackson and Keller, 1970], have an overall small effect, even if they grow on a suitable substrate, such as basalt which contains a large proportion of $\mathrm{Ca}$ and $\mathrm{Mg}$ silicates. Mineralogy and contact area are as important as the presence of the right weathering agent. Preliminary results using small basalt tiles indicate that carbonic acid alone can dissolve quite substantial amounts of $\mathrm{Ca}, \mathrm{Mg}$ and $\mathrm{Na}$ (work in progress, using the leachate recovered from the plant trays). Moulton et al. [2000] found most of the weathering observed on Iceland was under vascular plants as well as under mature forests growing on older (several thousand years) lava flows, presumably because the rock substrate was broken up, providing a larger surface area to be weathered as well as a greater input of $\mathrm{CO}_{2}$ from soil respiration. The Old Red Sandstone, whose original sediments provided the substrate for many of the first land plants, contains abundant feldspar to be weathered. The Ditton Group, for example, is made up of up to $20 \%$ feldspar [Allen, 1974]. The increase in chemical weathering during the mid-Palaeozoic was therefore not only dependent on the presence of vascular plants with extensive rooting systems, but also on a supply of rock fragments and the appropriate mineralogy of the sediment. Future estimates of a plant weathering factor over geological time should be based on a range of biomes, with a reasonable spatial resolution, to account for differences in vegetation type; they should also take into account the type of substrate available for colonization.

\section{Conclusions}

[32] The present study demonstrates the importance of rooted plant evolution for a stimulation of chemical weathering and the development of our present atmosphere. The magnitude of the substrate $\mathrm{CO}_{2}$ increase under elevated atmospheric $\mathrm{CO}_{2}$ was determined by the type of vegetation growing on the substrate: a cover of rooted tracheophytes increased substrate $\mathrm{CO}_{2}$ concentration more than a cover of nonrooted tracheophytes, bryophytes, algae, or no cover. This suggests that rooted tracheophytes have the potential to enhance chemical weathering on a larger scale than other vegetation types by facilitating the formation of carbonic acid within a soil. The increased weathering of silicate rocks, following the evolution of roots in the mid-Palaeozoic and the increased land area occupied by these plants, was largely responsible for the contemporaneous drop in atmospheric $\mathrm{CO}_{2}$ levels reported by other authors.

[33] Acknowledgments. We thank Dennis Wildman for help in conceiving the CEF; Carsten Müller for help with HPLC analysis; and Juliet Hynes for help with DHA analysis.

\section{References}

Aghamiri, R., and D. W. Schwartzman (2002), Weathering rates of bedrock by lichens: A mini watershed study, Chem. Geol., 188, 249-259, doi:10.1016/S0009-2541(02)00105-5.

Algeo, T. J., and S. E. Scheckler (1998), Terrestrial-marine teleconnections in the Devonian: Links between the evolution of land plants, weathering 
processes, and marine anoxic events, Philos. Trans. R. Soc. London, Ser $B$, 353, 113-130, doi:10.1098/rstb.1998.0195.

Allen, J. R. L. (1974), Sedimentology of the Old Red Sandstone (SiluroDevonian) in the Clee Hills area, Shropshire, England, Sed. Geol., 12, 73-167, doi:10.1016/0037-0738(74)90007-4.

Andrews, J. A., and W. H. Schlesinger (2001), Soil $\mathrm{CO}_{2}$ dynamics, acidification, and chemical weathering in a temperate forest with experimental $\mathrm{CO}_{2}$ enrichment, Global Biogeochem. Cycles, 15, 149-162, doi:10.1029/2000GB001278.

Baath, E., and H. Wallander (2003), Soil and rhizosphere microorganisms have the same $\mathrm{Q}(10)$ for respiration in a model system, Global Change Biol., 9, 1788-1791, doi:10.1046/j.1365-2486.2003.00692.x.

Basu, A. (1981), Weathering before the advent of land plants: Evidence from unaltered detrital K-feldspars in Cambrian-Ordovician arenites, Geology, 9, 132-133, doi:10.1130/0091-7613(1981)9<132:WBTAOL $>$ 2.0.CO;2.

Baxter, R., T. W. Ashenden, and J. F. Farrar (1997), Effect of elevated CO and nutrient status on growth, dry matter partitioning and nutrient content of Poa alpina var vivipara L, J. Exp. Bot., 48, 1477-1486, doi:10.1093/ jxb/48.7.1477.

Bennett, P. C., and W. Casey (1994), Chemistry and mechanisms of lowtemperature dissolution of silicates by organic acids, in Organic Acids in Geological Processes, edited by E. D. Pittman and M. D. Lewan, pp. 162-200, Springer, Berlin.

Berner, E. K., R. A. Berner, and K. L. Moulton (2003), Plants and minera weathering: Present and past, in Treatise on Geochemistry, vol. 5, Surface and Ground Water, Weathering, and Soils, edited by J. I. Drever, pp. 169 188, Elsevier, New Haven.

Berner, R. A. (1990), Atmospheric carbon dioxide levels over Phanerozoic time, Science, 249, 1382-1386, doi:10.1126/science.249.4975.1382.

Berner, R. A. (1992), Weathering, plants and the long-term carbon cycle, Geochim. Cosmochim. Acta, 56, 3225-3231, doi:10.1016/0016-7037(92) 90300-8.

Berner, R. A. (1997), The rise of plants and their effect on weathering and atmospheric $\mathrm{CO}_{2}$, Science, 276, 544-546, doi:10.1126/science.276. 5312.544 .

Berner, R. A. (1998), The carbon cycle and $\mathrm{CO}_{2}$ over Phanerozoic time: The role of land plants, Philos. Trans. R. Soc. London, Ser. B, 353, 75-82, doi:10.1098/rstb.1998.0192.

Berner, R. A., and Z. Kothavala (2001), Geocarb III: A revised model of atmospheric $\mathrm{CO}_{2}$ over Phanerozoic time, Am. J. Sci., 301, 182-204, doi:10.2475/ajs.301.2.182

Binet, F., L. Fayolle, M. Pussard, J. J. Crawford, S. J. Traina, and O. H. Tuovinen (1998), Significance of earthworms in stimulating soil microbial activity, Biol. Fertil. Soils, 27, 79-84, doi:10.1007/s003740050403.

Binkley, D., Y. Son, and D. W. Valentine (2000), Do forests receive occult inputs of nitrogen?, Ecosystems (N.Y., Print), 3, 321-331, doi:10.1007/ s100210000029.

Bohlen, P. J., P. M. Groffman, C. T. Driscoll, T. J. Fahey, and T. G. Siccama (2001), Plant-soil-microbial interactions in a northern hardwood forest, Ecology, 82, 965-978.

Bormann, B. T., D. Wang, F. H. Bormann, G. Benoit, R. April, and M. C. Snyder (1998), Rapid, plant-induced weathering in an aggrading experimental ecosystem, Biogeochemistry, 43, 129-155, doi:10.1023/A: 1006065620344

Boucot, A. J., and J. Gray (2001), A critique of Phanerozoic climatic models involving changes in the $\mathrm{CO}_{2}$ content of the atmosphere, Earth Sci. Rev., 56, 1-159, doi:10.1016/S0012-8252(01)00066-6.

Brady, P. V., and S. A. Carroll (1994), Direct effects of $\mathrm{CO}_{2}$ and temperature on silicate weathering: Possible implications for climate control, Geochim. Cosmochim. Acta, 58, 1853-1856, doi:10.1016/00167037(94)90543-6.

Brady, P. V., and J. M. Zachara (1996), Geochemical applications of mineral surface science, in Physics and Chemistry of Mineral Surfaces, edited by P. V. Brady, pp. 307-356, CRC Press, Boca Raton, Fla.

Brantley, S. L. (2003), Reaction kinetics of primary rock-forming minerals under ambient conditions, in Treatise on Geochemistry, vol. 5, Surface and Ground Water, Weathering, and Soils, edited by J. I. Drever, pp. $73-$ 117, Elsevier, New Haven.

Busenberg, E., and C. V. Clemency (1976), The dissolution kinetics of feldspars at $25 \mathrm{C}$ and $1 \mathrm{~atm} \mathrm{CO}_{2}$ partial pressure, Geochim. Cosmochim. Acta, 40, 41-49, doi:10.1016/0016-7037(76)90192-7.

Cardon, Z. G. (1996), Influence of rhizodeposition under elevated $\mathrm{CO}_{2}$ on plant nutrition and soil organic matter, Plant Soil, 187, 277-288, doi:10.1007/BF00017093.

Chiu, C. Y., M. K. Wang, J. L. Hwong, and H. B. King (2002), Physical and chemical properties in rhizosphere and bulk soils of Tsuga and Yushania in a temperate rain forest, Commun. Soil Sci. Plant Anal., 33, $1723-$ 1735, doi:10.1081/CSS-120004818.

Dakora, F. D., and D. A. Phillips (2002), Root exudates as mediators of mineral acquisition in low-nutrient environments, Plant Soil, 245, 3547, doi:10.1023/A:1020809400075.

Dessert, C., B. Dupre, J. Gaillardet, L. M. Francois, and C. J. Allegre (2003), Basalt weathering laws and the impact of basalt weathering on the global carbon cycle, Chem. Geol., 202, 257-273, doi:10.1016/ j.chemgeo.2002.10.001.

Douce, K. G., and D. A. Crossley Jr. (1982), The effect of soil fauna on litter mass loss and nutrient loss dynamics in Arctic tundra at Barrow, Alaska, Ecology, 63, 523-537, doi:10.2307/1938968.

Drever, J. I., and G. F. Vance (1994), Role of soil organic acids in mineral weathering processes, in Organic Acids in Geological Processes, edited by E. D. Pittman and M. D. Lewan, pp. 138-161, Springer, Berlin.

Driese, S. G., C. I. Mora, and J. M. Elick (2000), The Paleosol record of increasing plant diversity and depth of rooting and changes in atmospheric $\mathrm{CO}_{2}$ in the Siluro-Devonian, in Phanerozoic Terrestrial Ecosystems, Pal. Soc. Pap., 6, 47-62.

Edwards, D. (2003), Xylem in early tracheophytes, Plant Cell Environ., 26, 57-72, doi:10.1046/j.1365-3040.2003.00878.x.

Edwards, D., and P. A. Selden (1993), The development of early terrestrial ecosystems, Bot. J. Scotl., 46, 337-366.

Gensel, P. G., and C. M. Berry (2001), Early lycophyte evolution, Am. Fern J., 91, 74-98, doi:10.1640/0002-8444(2001)091[0074:ELE]2.0.CO;2.

Ghosh, P., S. K. Bhattacharya, and R. A. Jani (1995), Palaeoclimate and palaeovegetation in central India during the Upper Cretaceous based on stable isotope composition of the palaeosol carbonates, Palaeogeogr. Palaeoclimatol. Palaeoecol., 114, 285-296, doi:10.1016/0031-0182(94) 00082-J.

Gorissen, A. (1996), Elevated $\mathrm{CO}_{2}$ evokes quantitative and qualitative changes in carbon dynamics in a plant/soil system: Mechanisms and implications, Plant Soil, 187, 289-298, doi:10.1007/BF00017094.

Gray, J. (1993), Major Paleozoic land plant evolutionary bio-events, $\mathrm{Pa}$ laeogeogr. Palaeoclimatol. Palaeoecol., 104, 153-169, doi:10.1016/ 0031-0182(93)90127-5.

Heisler, C. (1994), Significance of microflora, mesofauna and macrofauna for the decomposition of straw in differently compacted arable soils, Zool. Anz., 233, 153-172.

Högberg, P., A. Nordgren, N. Buchmann, A. F. S. Taylor, A. Ekblad, M. N. Högberg, G. Nyberg, M. Ottosson-Löfvenius, and D. J. Read (2001), Large-scale forest girdling shows that current photosynthesis drives soil respiration, Nature, 411, 789-792, doi:10.1038/35081058.

Holland, H. D. (1978), The Chemistry of the Atmosphere and Oceans, 351 pp., John Wiley, New York.

Jackson, T. A., and W. D. Keller (1970), A comparative study of the role of lichens and 'inorganic' processes in the chemical weathering of recent Hawaiian lava flows, Am. J. Sci., 269, 446-466.

Jones, D. L., P. R. Darrah, and L. V. Kochian (1996), Critical evaluation of organic acid mediated iron dissolution in the rhizosphere and its potential role in root iron uptake, Plant Soil, 180, 57-66, doi:10.1007/BF00015411.

Keller, C. K., and B. D. Wood (1993), Possibility of chemical weathering before the advent of vascular plants, Nature, 364, 223-225, doi:10.1038/ $364223 \mathrm{a} 0$

Kerp, H., H. Hass, and V. Mosbrugger (2001), New data on Nothia aphylla Lyon 1964 ex El-Saadawy et Lacey 1979, a poorly known plant from the Lower Devonian Rhynie Chert, in Plants Invade the Land, edited by P. G. Gensel and D. Edwards, pp. 52-82, Columbia Univ. Press, New York. Killham, K. (1994), Soil Ecology, 242 pp., Cambridge Univ. Press, Cambridge, UK.

Lambers, H., I. Stulen, and A. van der Werf (1996), Carbon use in root respiration as affected by elevated atmospheric $\mathrm{O}_{2}$, Plant Soil, 187, 251263, doi:10.1007/BF00017091.

Lawton, J. H. (1996), The Ecotron facility at Silwood Park: The value of "big bottle" experiments, Ecology, 77, 665-669, doi:10.2307/2265488.

McElwain, J. C., and W. G. Chaloner (1995), Stomatal density and index of fossil plants track atmospheric carbon dioxide in the Palaeozoic, Ann. Bot. (London), 76, 389-395, doi:10.1006/anbo.1995.1112.

Mora, C. I., S. G. Driese, and P. G. Seager (1991), Carbon dioxide in the Paleozoic atmosphere: Evidence from carbon-isotope compositions of pedogenic carbonate, Geology, 19, 1017-1020, doi:10.1130/00917613(1991)019<1017:CDITPA > 2.3.CO;2.

Moteetee, A., J. G. Duckett, and A. J. Russell (1996), Mycorrhizas in the ferns of Lesotho, in Pteridology in Perspective, edited by J. M. Camus, M. Gibby, and R. J. Johns, pp. 621-631, Royal Botanic Gardens, Kew, UK.

Moulton, K. L., J. West, and R. A. Berner (2000), Solute flux and mineral mass balance approaches to the quantification of plant effects on silicate 
weathering, Am. J. Sci., 300, 539-570, doi:10.2475/ajs.300.7.539.

Nguyen, C. (2003), Rhizodeposition of organic C by plants: Mechanisms and controls, Agronomie, 23, 375-396, doi:10.1051/agro:2003011.

Nisbet, E. G., and C. M. R. Fowler (1999), Archean metabolic evolution of microbial mats, Proc. R. Soc. London, Ser. B, 266, 2375-2382, doi:10.1098/rspb.1999.0934.

Oh, N.-H., and D. D. Richter (2004), Soil acidification induced by elevated atmospheric $\mathrm{CO}_{2}$, Global Change Biol., 10, 1936-1946, doi:10.1111/ j.1365-2486.2004.00864.x.

Öhlinger, R. (1996), Dehydrogenase activity with the substrate TTC, in Methods in Soil Biology, edited by F. Schinner et al., pp. 241-243, Springer, Berlin

Poole, I., T. Lawson, J. D. B. Weyers, and J. A. Raven (2000), Effect of elevated $\mathrm{CO}_{2}$ on the stomatal distribution and leaf physiology of Alnus glutinosa, New Phytol., 145, 511-521, doi:10.1046/j.1469-8137.2000. 00589.x.

Raven, J. A., and D. Edwards (2001), Roots: Evolutionary origins and biogeochemical significance, J. Exp. Bot., 52, 381-401.

Retallack, G. J. (1997), Early forest soils and their role in Devonian global change, Science, 276, 583-585, doi:10.1126/science.276.5312.583.

Russell, E. W. (1973), Soil Conditions and Plant Growth, 849 pp., Longman Group, London.

Ryan, P. R., E. Delhaize, and D. L. Jones (2001), Function and mechanism of organic anion exudation from plant roots, Annu. Rev. Plant Physiol. Plant Mol. Biol., 52, 527-560, doi:10.1146/annurev.arplant.52.1.527.
Saralabai, V. C., M. Vivekanandan, and R. S. Babu (1997), Plant responses to high $\mathrm{CO}_{2}$ concentration in the atmosphere, Photosynthetica, 33, 7-37, doi:10.1023/A:1022118909774.

Scott-Denton, L. E., T. N. Rosenstiel, and R. K. Monson (2006), Differential controls by climate and substrate over the heterotrophic and rhizospheric components of soil respiration, Global Change Biol., 12, $205-$ 216, doi:10.1111/j.1365-2486.2005.01064.x.

Stöcklin, J., and C. Körner (1999), Interactive effects of elevated $\mathrm{CO}_{2}$, $\mathrm{P}$ availability and legume presence on calcareous grassland: Results of a glasshouse experiment, Funct. Ecol., 13, 200-209, doi:10.1046/j.13652435.1999.00308.x.

Tomescu, A. M. F., G. W. Rothwell, and R. Honegger (2006), Cyanobacterial macrophytes in an Early Silurian (Llandovery) continental biota: Passage Creek, lower Massanutten Sandstone, Virginia, USA, Lethaia, 39, 329-338, doi:10.1080/00241160600876719.

Urey, H. C. (1952), The Planets: Their Origin and Development, 245 pp., Oxford Univ. Press, London.

Wright, V. P. (1985), The precursor environment for vascular plant colonization, Philos. Trans. R. Soc. London, Ser. B, 309, 143-145, doi:10.1098/ rstb.1985.0075.

C. Baars, Department of Geology, National Museum Wales, Cathays Park, Cardiff CF10 3NP, UK. (christian.baars@museumwales.ac.uk)

D. Edwards, School of Earth, Ocean and Planetary Sciences, Cardiff University, Main Building, Park Place, Cardiff CF10 3YE, UK.

T. Hefin Jones, School of Biosciences, Cardiff University, Cardiff CF10 3US, UK. 